izv. prof. dr. sc. Andrijana Rogošić

Sveučilište u Splitu, Ekonomski fakultet, Split, Republika Hrvatska arogosic@efst.hr

\title{
POZNAVANJE RAČUNOVODSTVA U NEPROFITNIM ORGANIZACIJAMA I NJEGOV UTJECAJ NA POSLOVNO ODLUČIVANJE I FINANCIJSKO PLANIRANJE
}

Primljen: 28. listopada 2019.

Prihvaćen: 6 . prosinac 2019.

https://doi.org/10.46458/27121097.2021.27.9

\section{Prethodno priopćenje}

\section{Sažetak}

Neprofitne organizacije karakterizira usmjerenost na unaprjeđenje civilnog društva, ali unatoč tome što im ostvarivanje dobiti ne predstavlja cilj, njihovo poslovanje postaje nalik poduzetnicima jer se susreću s jakom konkurencijom pri realizaciji donacija i zahtjevima interesnih skupina za povećanom djelotvornošću. Novi konceptualni okviri upravljanja neprofitnim organizacijama stavljaju naglasak na upravljanje performansama i financijski menadžment oslanjajući se pri tom na računovodstvene informacije. Stoga, razumijevanje računovodstva postaje ključno za uspješno djelovanje neprofitnih organizacija. Međutim, za razliku od poduzeća koja zapošljavaju ekonomiste (koji poznaju računovodstvo), u neprofitnom sektoru ovaj profil stručnjaka je često deficitaran pa se postavlja pitanje razumijevanja $i$ korištenja računovodstvenih informacija. Empirijskim istraživanjem je utvrđeno da u neprofitnim organizacijama u Hrvatskoj poznavanje računovodstva ima prostora za napredak. Potvrđene su hipoteze koje se odnose na pozitivan utjecaj poznavanja računovodstva na odlučivanje i financijsko planiranje.

Ključne riječi: računovodstvo, neprofitne organizacije, odlučivanje, financijsko planiranje

JEL: M41 


\section{UVOD}

Važnost poznavanja i korištenja računovodstvenih informacija za potrebe upravljanja i poslovnog odlučivanja je literaturi mnogo puta istaknuta (Ježovita, 2015; Mamić Sačer, Dečman i Rep, 2018; Royaee, Salehi i Aseman, 2012, Tunji, 2012; Žager i Dečman, 2015). Međutim, dosadašnja istraživanja o povezanosti računovodstva i upravljanja su uglavnom provedena na poduzetnicima, a o navedenom odnosu u neprofitnim organizacijama nema dovoljno empirijskih potvrda.

Neprofitne organizacije (u užem smislu) predstavljaju rastući segment demokratskog društva te su često nazivane trećim sektorom. Riječ je o nevladinim organizacijama koje u svom djelovanju stavljaju naglasak na općekorisnim i dobrotvornim aktivnostima. Njihov utjecaj u kreiranju politika je sve jači diljem svijeta (Guay, Doh i Sinclair, 2004; Reimann, 2006; Werker i Ahmed, 2008) stoga je $\mathrm{i}$ interes različitih interesnih skupina za njihov rad sve veći. U interesne skupine neprofitnih organizacija najčešće se ubrajaju njihovi korisnici, članovi, volonteri, zaposlenici, donatori, ali i šira javnost. Odnos neprofitne organizacije s pojedinim interesnim skupinama determinirana je vrstom djelatnosti, misijom i ciljevima (Mihanović, Pavičić i Alfirević, 2014). Svim interesnim skupinama temeljne informacije o financijskom položaju i rezultatu neprofitnih organizacija su dostupne putem Registra neprofitnih organizacija u Republici Hrvatskoj. Informacije sadržane u bilanci, računu prihoda i rashoda (za obveznike dvojnog knjigovodstva), odnosno u godišnjem financijskom izvješću o primicima i izdacima (za one koji primjenjuju jednostavno knjigovodstvo) omogućuju osnovni uvid u poslovanje te mogu poslužiti u odlučivanju ne samo eksternim korisnicima (interesnim skupinama), nego prvenstveno internim korisnicima (a posebice vodstvu neprofitne organizacije) ukoliko poznaju računovodstvo.

Cilj ovog istraživanja provedenog nad neprofitnim organizacijama koje djeluju na teritoriju Republike Hrvatske je utvrditi utjecaj poznavanja računovodstva na bolje korištenje računovodstvenih informacija, poslovno odlučivanje i financijsko planiranje. Pretpostavlja se da je uloga računovodstva u upravljanju neprofitnim organizacijama bitna iz razloga što je u suvremenom okruženju naglasak na djelotvornom i učinkovitom poslovanju. Kako Aboramadan (2018) ističe, malo pažnje je posvećeno racionalnosti, djelotvornosti, učinkovitosti i ekonomskoj održivosti u upravljanju neprofitnim organizacijama. Naime, neprofitne organizacije djeluju u iznimno kompetitivnom okruženju te u borbi za financijska sredstva trebaju dokazati svoju učinkovitost (Goerke, 2003; Speckbacher 2003; Tucker i Parker, 2013). Iz navedenog razloga je za očekivati da zakonski predstavnici tj. uprava neprofitne organizacije teži računovodstvenom opismenjavanju odnosno da znanje računovodstva može pomoći u izbjegavanju poslovnih rizika i, posljedično, donošenju boljih poslovnih odluka. 
U nastavku rada elaborirana je važnost poznavanja računovodstva posebno pri donošenju odluka i upravljanju. U trećem dijelu je prikazan pregled dosadašnjih empirijskih istraživanja o računovodstvu neprofitnih organizacija. Uvid u rezultate prethodnih istraživanja doveo je do postavljanja hipoteza navedenih u četvrtom dijelu ovog rada. Metodologija istraživanja kao i empirijski testirani rezultati su pojašnjeni u petom dijelu nakon čega slijede zaključna razmatranja.

\section{VAŽNOST POZNAVANJA RAČUNOVODSTVA ZA POTREBE ODLUČIVANJA I PLANIRANJA}

Obzirom na izraženu dinamičnost okruženja u kojem poslovni subjekti djeluju od iznimne je važnosti za odlučivanje i upravljanje svaka relevantna informacija pa tako i ona računovodstvene prirode. U svrhu uspješnog upravljanja organizacijom neophodne su ažurne, relevantne, potpune i pouzdane računovodstvene informacije. Računovodstvene informacije navedenih atributa imaju ključnu ulogu u poslovnom odlučivanju (Tunji, 2012).

Naime, prva istraživanja o ulozi računovodstva u procesu donošenja odluka datiraju iz šezdesetih godina prošlog stoljeća (Socea, 2012). Empirijska istraživanja upućuju na zaključak da se prilikom odlučivanja najviše koriste informacije koje pruža financijsko računovodstvo (Eierle i Schultze, 2013; Ježovita, 2015, Nogueira i Jorge, 2017). Jedna od temeljnih zadaća financijskog računovodstva sastavljanje financijskih izvještaja namijenjenih različitim korisnicima, a računovodstvene informacije objavljenje u njima su najčešće korištene kao podloga za poslovno odlučivanje. Međutim, financijski izvještaji ne pružaju sve informacije koje bi korisnici mogli trebati pri donošenju ekonomskih odluka, budući da one uglavnom daju sliku financijskih učinaka prošlih događaja i obično ne pružaju nefinancijske informacije. Ipak, financijski izvještaji sadrže temeljne računovodstvene informacije, a poznavanje računovodstvene terminologije je preduvjet za njihovo razumijevanje i tumačenje. Istraživanjem provedenim na mikro, malim i srednjim poduzetnicima u Hrvatskoj (Mamić Sačer i sur., 2018) je utvrđeno da menadžeri (koji su nerijetko i vlasnici) nisu u potpunosti upoznati s računovodstvenom terminologijom. U spomenutom istraživanju je uočeno da je samo $37 \%$ ispitanika prepoznalo u potpunosti stavke financijskih izvještaja. Budući da osobe ovlaštene za zastupanje neprofitnih organizacija kao i menadžeri-vlasnici mikro poduzeća često nemaju adekvatnu ekonomsku izobrazbu, postavlja se pitanje njihovog poznavanja računovodstva i korištenja istog za potrebe odlučivanja i upravljanja. Empirijskim istraživanjem provedenim u Hrvatskoj, Ježovita (2015) je utvrdila da se računovodstvene informacije u procesu donošenja odluka najčešće koriste za analizu postignuća poslovnih rezultata i za pripremu poslovnih planova. Najčešće se korite računovodstvene informacije sadržane u financijskim 
izvještajima, a nešto manje informacije izravno preuzete iz računovodstvenog sustava. Rezultati navedenog istraživanja (Ježovita, 2015, str. 71) ukazuju na to da $75 \%$ ispitanika koristi računovodstvene informacije u odlučivanju. Jedan od razloga zašto se menadžeri oslanjaju na računovodstvene informacije je što takve informacije proizlaze iz najviše reguliranog informacijskog sustava. Bez dobro ustrojenog računovodstvenog sustava nema ni kvalitetne informacijske podloge, kako za potrebe internih, tako ni za potrebe eksternih korisnika (Žager i Dečman, 2015, str. 53).

\section{DOSADAŠNJA ISTRAŽIVANJA O RAČUNOVODSTVENOJ PRAKSI NEPROFITNIH ORGANIZACIJA}

Širenje nevladinih udruga na područja koja je ranije pokrivala država predmet je različitih dilema. Postavljaju se brojna pitanja glede njihove nadležnosti (Unerman i O'Dwyer, 2006) poput razine odgovornosti nad pruženim uslugama koje su nekoć bile pod okriljem državnih institucija, mehanizama nadzora izvođenja njihovih usluga, učinkovitosti neprofitnih organizacija i slično. Uvidom u prethodna istraživanja Paiva i Carvalho (2018) su utvrdili da neprofitni sektor obavlja bitne društvene, ekonomske i političke funkcije. Snaga civilnog društva (neprofitnih organizacija) ogleda se u njihovom globalnom utjecaju poput efekta na novi javni menadžment (neprofitne organizacije utječu na kreiranje politika), stvaranje društvenog kapitala (kada neprofitne organizacije stječu povjerenje kroz umrežavanje) i aktivizma (Gray, Bebbington i Collison, 2006). Neprofitne organizacije pružaju čitav niz usluga sukladno djelatnostima za koje su registrirane, a obzirom na njihov pravni oblik u Hrvatskoj se razlikuju:

- udruge (i njihovi savezi) definirane kao svaki oblik slobodnog i dobrovoljnog udruživanja više fizičkih, odnosno pravnih osoba koje se, radi zaštite njihovih probitaka ili zauzimanja za zaštitu ljudskih prava i sloboda, zaštitu okoliša i prirode i održivi razvoj, te za humanitarna, socijalna, kulturna, odgojno-obrazovna, znanstvena, sportska, zdravstvena, tehnička, informacijska, strukovna ili druga uvjerenja i ciljeve koji nisu u suprotnosti s Ustavom i zakonom, a bez namjere stjecanja dobiti ili drugih gospodarski procjenjivih koristi, podvrgavaju pravilima koja uređuju ustroj i djelovanje toga oblika udruživanja i koja stječe pravnu osobnost danom upisa u Registar udruga Republike Hrvatske (Zakon o udrugama, Narodne novine, br.74/14, 70/17).

- zaklade i fundacije pri čemu je zaklada imovina namijenjena da sama, prihodima što ih stječe, trajno služi ostvarivanju neke općekorisne ili dobrotvorne svrhe, dok je fundacija imovina namijenjena ostvarivanju neke 
općekorisne ili dobrotvorne svrhe u određenom vremenskom razdoblju (Zakon o zakladama i fundacijama, Narodne novine, br. 36/95, 64/01).

- ustanove u slučaju da se osniva za trajno obavljanje djelatnosti odgoja i obrazovanja, znanosti, kulture, informiranja, športa, tjelesne kulture, tehničke kulture, skrbi o djeci, skrbi o invalidima i druge djelatnosti, koje ne obavlja radi stjecanja dobiti (Zakon o ustanovama, Narodne novine, br. 76/93, 29/97, 47/99, 35/08).

- političke stranke odnosno pravne osobe koje politički djeluju u skladu s ciljevima utvrđenim programom i statutom (Zakon o političkim strankama, Narodne novine, br. 76/93, 111/96, 164/98, 36/01, 28/06).

- komore koje predstavljaju udruženja pretežito strukovnog obilježja.

- sindikati se mogu definirati kao organizacije koje stvaraju radnici i koje predstavljaju radnike u određenoj gospodarskoj grani ili u određenoj organizaciji, a uspostavljaju se kako bi poboljšalo (ili bar održalo na istoj razini) radne uvjete, plaće i naknade. Sindikati se obično ujedinjuju u udruge sindikata i sindikalne središnjice.

- vjerske i druge zajednice koje obuhvaćaju fizičke osobe koje ostvaruju slobodu vjeroispovijedi jednakim javnim obavljanjem vjerskih obreda $\mathrm{i}$ drugim očitovanjima svoje vjere, upisane u Evidenciju vjerskih zajednica u Republici Hrvatskoj (Zakon o pravnom položaju vjerskih zajednica, Narodne novine, br. 83/02, 73/13).

Navedene neprofitne organizacije su obveznice primjene Zakona o financijskom poslovanju i računovodstvu neprofitnih organizacija (Narodne novine, br. 121/14) koji zajedno s tri pravilnika: Pravilnikom o neprofitnom računovodstvu i računskom planu (Narodne novine, br. 1/15), Pravilnikom o izvještavanju u neprofitnom računovodstvu i Registru neprofitnih organizacija (Narodne novine, br. 31/15) i Pravilnikom o sustavu financijskog upravljanja i kontrola, izradi i izvršavanju financijskih planova neprofitnih organizacija (Narodne novine, br. 119/15) predstavlja regulatorni računovodstveni okvir. Ova nova regulativa je u funkciji povećanja odgovornosti, učinkovitosti te financijske transparentnosti neprofitnih organizacija. Stupanjem na snagu Zakona o financijskom poslovanju i računovodstvu neprofitnih organizacija 2015. godine po prvi puta se u Hrvatskoj uređuje područje financijskog poslovanja neprofitnih organizacija. Ovim okvirom su stvoreni uvjeti učinkovitog i djelotvornog sustava financijskog upravljanja i kontrola kao i mogućnost da svaka neprofitna organizacija pokaže da zakonito, namjenski i svrhovito raspolaganje sredstvima. Nastavno na navedeno, empirijskim istraživanjem (Soobaroyen i Sannassee, 2007: 290) je utvrđeno da je u neprofitnom sektoru prioritet stavljen na adekvatnu računovodstvenu evidenciju, 
izvještavanje sukladno propisima (i eventualnim zahtjevima donatora), te održavanju solventnosti. Paiva i Carvalho (2018: 38) su utvrdile da većina neprofitnih organizacija u Angoli prepoznaju važnost računovodstva i korisnost planiranja i budžetiranja. Rezultati istraživanja provedenog u Južnoj Karolini (SAD) ukazuju na iznimnu učinkovitost računovodstvenog sustava neprofitnog sektora u postizanju financijske odgovornosti i organizacijskih ciljeva (Maguire, 2012).

Kao važno obilježje neprofitnih organizacija u Hrvatskoj ističe se eksternalizacija računovodstvene funkcije (Rogošić i Svirčić, 2015; Vašiček, Dragija Kostić i Žmuk, 2017). Naime, većina neprofitnih organizacija ne zapošljava računovođu nego vođenje poslovnih knjiga i sastavljanje financijskih izvještaja najčešće prepušta subjektima specijaliziranim za računovodstvene usluge (knjigovodstvenim servisima). Sukladno rezultatima empirijskog istraživanja (Vašiček i sur., 2017) kao primarni korisnici računovodstvenih informacija se javljaju zakonski zastupnici neprofitnih organizacija u većini slučajeva, a potom slijede drugi interni korisnici poput voditelja projekata i ostalih menadžera. Rogošić i Svirčić (2015) su utvrdile da su humanitarne organizacije s internaliziranim računovodstvenim sustavom u prednosti u odnosu na one kojima poslovne knjige vode knjigovodstveni servisi jer imaju dostupnije informacije korištene za planiranje. Slično kao kod poduzeća (Ježovita, 2015), humanitarne organizacije u Hrvatskoj kreiraju strateške planove oslanjajući se na računovodstvene informacije (Rogošić i Svirčić, 2015). Potonjim istraživanjem je utvrđeno da širi opseg računovodstvenih informacija korišten za odlučivanje omogućuje bolju kontrolu performansi.

U svom konceptualnom radu Aboramadan (2018) predlaže okvir za uspješno upravljanje neprofitnim organizacijama čiji su elementi: strateški menadžment, marketing, upravljanje ljudskim resursima, logistika i upravljanje opskrbnim lancem, upravljanje projektima, organizacijska kultura i učenje, upravljanje performansama i financijski menadžment. Uloga računovodstva u uspješnom upravljanju neprofitnim organizacijama je, sukladno predloženom modelu, od iznimne važnosti posebice pri mjerenju performansi i financijskom menadžmentu.

\section{HIPOTEZE}

Uvidom u prethodno opisanu literaturu dolazi se do zaključka da bi računovodstveni sustav neprofitnih organizacija mogao biti vrijedan izvor informacija internim korisnicima jednako kao i u poduzećima. Jedan od razloga počiva na aktualnim okolnostima djelovanja neprofitnih organizacija. Naime, neprofitne organizacije se kao i poduzeća susreću s jakom konkurencijom i dinamičnim okruženjem. Posljedično, organizacija i upravljanje neprofitnim organizacijama postaju sve sličnija poduzećima. Postoje prijepori glede korištenja računovodstvenih informacija 
u neprofitnom sektoru. Jegers (2008) smatra da se računovodstvene informacije ne koriste dovoljno u neprofitnim organizacijama te da postoji velika razlika $\mathrm{u}$ korištenju istih između profitnog i neprofitnog sektora koja počiva u različitosti ciljeva i poznavanja računovodstva. S druge strane, brojni autori promoviraju primjenu različitih računovodstvenih metoda u neprofitnom sektoru (Dražić Lutilsky i Prša Krunić, 2012; Hall i Millo, 2018; Kaplan, 2001). Mjerenje performansi, koje počiva na računovodstvenim informacijama, se zagovara u novijim istraživanjima (Aboramadan, 2018; Amagoh, 2015) jer je u funkciji učinkovitosti i održivosti neprofitnih organizacija. Sve prethodno navedeno upućuje na ključnu ulogu koje ima poznavanje računovodstva u neprofitnim organizacijama pa su, stoga, postavljene sljedeće istraživačke hipoteze:

$\mathrm{H}_{1}$ : Bolje poznavanje računovodstva pozitivno utječe na konzultiranje stručne (računovodstveno-financijske) literature, redovito korištenje usluga profesionalnog savjetovanja na području računovodstva i redovito informiranje o računovodstvenim propisima.

$\mathrm{H}_{2}$ : Bolje poznavanje računovodstva pozitivno utječe na donošenje poslovnih odluka, financijsku pismenost koja umanjuje rizike kod donošenja poslovnih odlu$\mathrm{ka}$, bolje financijsko planiranje, ali i na svjesnost o prednostima vođenja poslovnih knjiga unutar organizacije.

\section{REZULTATI ISTRAŽIVANJA}

\subsection{Metodologija istraživanja}

Empirijsko istraživanje provedeno je putem on-line ankete koja je kreirana na Google-docs platformi te je poslana na 1.500 elektronskih adresa neprofitnih organizacija iz Registra neprofitnih organizacija Republike Hrvatske. Anketi se odazvalo 225 predstavnika neprofitnih organizacija što čini anketni povrat od 15\%. Istraživanje je provedeno u razdoblju od srpnja do studenog 2017.

Većina pitanja su imala ponuđene rangirane odgovore koje su ispitanici vrednovali na Likertovoj skali od 1 do 5 pri čemu je 1 - „u potpunosti se ne slažem“, a 5 - „u potpunosti se slažem“. Uvodna pitanja su bila demografskog karaktera, a uključuju i pitanje o području kao i o stupnju obrazovanja ispitanika.

Prikupljeni podatci su statistički obrađeni korištenjem dvaju programa: SPSS 17.0 i MS Excel. Rezultati koji se odnose na demografske podatke su objašnjeni temeljem deskriptivne statistike, a hipoteze provjerene provedbom Jonckheere-Terpstra testa (univarijantna statistika). 


\subsection{Testiranje hipoteza}

$\mathrm{Na}$ otvoreno pitanje o području obrazovanja odgovori su bili raznovrsni te je utvrđeno da ispitanici imaju različito formalno obrazovanje (od umjetničkih, humanističkih pa do tehničkih područja), a što se tiče samog stupnja obrazovanja utvrđeno je sljedeće (Tablica 1).

Tablica 1: Stupanj obrazovanja ispitanika i njihova uloga $\mathrm{u}$ neprofitnim organizacijama

\begin{tabular}{cc|c|c|c|c}
\hline \hline & & \multicolumn{3}{|c|}{ Pozicija } & \multirow{2}{*}{ ukupno } \\
\cline { 3 - 5 } & & zaposlenik & volonter & zastupnik & 61 \\
\cline { 1 - 5 } Stupanj obrazo- & SSS & 8 & 11 & 42 & 41 \\
& VŠS & 9 & 5 & 27 & 95 \\
& VSS & 22 & 15 & 58 & 21 \\
& Magisterij & 5 & 4 & 12 & 7 \\
& Doktorat & 1 & 2 & 4 & 225 \\
\hline \multicolumn{2}{c|}{ Ukupno } & 45 & 37 & 143 & \\
\hline
\end{tabular}

Izvor: Izrada autorice

Većina ispitanika koja su ujedno kontakt osobe u anketiranim organizacijama su visokoobrazovani, a njihova uloga u neprofitnoj organizaciji je pretežito menadžerska jer se njih 64\% izjasnilo da su zakonski zastupnici.

Razina računovodstvenog informiranja iz različitih izvora i korištenja računovodstvenih informacija $u$ razne svrhe je utvrđena deskriptivnom statistikom čiji pregled je prikazan u Tablici 2 .

Tablica 2: Računovodstveno informiranje i korištenje računovodstvenih informacija u neprofitnim organizacijama

\begin{tabular}{l|c|c|c|c|c}
\hline & $\mathrm{N}$ & Minimum & Maximum & $\begin{array}{c}\text { Srednja } \\
\text { vrijednost }\end{array}$ & $\begin{array}{c}\text { Std. } \\
\text { devijacija }\end{array}$ \\
\hline $\begin{array}{l}\text { Računovodstvena } \\
\text { literatura }\end{array}$ & 225 & 1,00 & 5,00 & 3,4222 & 1,27281 \\
$\begin{array}{l}\text { Računovodstveno } \\
\text { savjetovanje }\end{array}$ & 225 & 1,00 & 5,00 & 3,1378 & 1,44656 \\
$\begin{array}{l}\text { Računovodstveni } \\
\text { propisi }\end{array}$ & 225 & 1,00 & 5,00 & 3,5511 & 1,20576 \\
$\begin{array}{l}\text { Odlučivanje } \\
\begin{array}{l}\text { Smanjena rizičnost } \\
\text { Financijsko }\end{array}\end{array}$ & 225 & 1,00 & 5,00 & 4,2222 &, 91829 \\
planiranje & 225 & 1,00 & 5,00 & 4,4222 &, 86316 \\
$\begin{array}{l}\text { Internalizirano } \\
\text { računovodstvo }\end{array}$ & 225 & 1,00 & 5,00 & 3,7644 & 1,14665 \\
\hline
\end{tabular}

Izvor: Izrada autorice 
Na skali od 1 do 5 je ocijenjena učestalost računovodstvenog informiranja temeljem računovodstveno-financijske stručne literature, profesionalnog računovodstvenog savjetovanja i praćenja računovodstvenih propisa. Od navedenih izvora informiranja o računovodstvu (Tablica 2) najbolje su ocijenjeni računovodstveni propisi iako je srednja vrijednost samo 3,55. Računovodstveni propisi tj. njihovo praćenje predstavlja najosnovniji segment informiranosti i odnosi se samo na legislativu. Obzirom da je računovodstvena regulativa u posljednjem desetljeću doživjela ozbiljne izmjene i uvela brojne dodatne zahtjeve, a i činjenica da je uvid $\mathrm{u}$ istu besplatan (za razliku od korištenja usluga računovodstvenog savjetovanja) ne iznenađuje ovakav empirijski nalaz. Učestalost korištenja različitih izvora informiranja o računovodstvenim pitanjima detaljnije je prikazana Grafikonom 1.

Grafikon 1: Učestalost informiranja o računovodstvu (odvojen u zasebnom dokumentu)

Korištenje računovodstvenih informacija za odlučivanje ima srednju ocjenu 4,22, a stav ispitanika prema kojem financijska pismenost umanjuje rizike kod donošenja poslovnih odluka je prosječno ocijenjen s 4,42 (Tablica 2). Obzirom da je izrada financijskih planova propisana Pravilnikom o sustavu financijskog upravljanja i kontrola, izradi i izvršavanju financijskih planova neprofitnih organizacija (Narodne novine, br. 119/15) najviša prosječna ocjena od 4,45 je, ujedno, i očekivana. Ispitan je i stav glede vođenja poslovnih knjiga unutar neprofitne organizacije prema kojem, u tom slučaju, postoji veća mogućnost za bolje upravljanje organizacijom te je utvrđena prosječna ocjena od 3,76, a samim time i mišljene većine ispitanika o prednosti internalizacije računovodstva.

Neparametrijskim testom (Tablica 3 i 4) je provjerena utemeljenost hipoteza. Rezultati prikazani u sljedećoj tablici ukazuju na osnovanost $\mathrm{H}_{1}$ hipoteze.

Tablica 3: Rezultati Jonckheere-Terpstra testa za prvu hipotezu

\begin{tabular}{l|c|c|c}
\cline { 2 - 4 } & literatura & savjetovanje & propisi \\
\hline Broj razina u Poznavanje računovodstva & 5 & 5 & 5 \\
N & 225 & 225 & 225 \\
Promatrana J-T statistika & 10914,000 & 11614,500 & 13776,000 \\
Srednja J-T statistika & 9112,000 & 9112,000 & 9112,000 \\
Std. devijacija oJ-T statistike & 523,636 & 526,476 & 521,547 \\
Std. J-T statistika & 3,441 & 4,753 & 8,943 \\
Signifikantnost (dvostrana) &, 001 &, 000 &, 000 \\
\hline
\end{tabular}

*Nezavisna varijabla: Poznavanje

računovodstva

Izvor: Izrada autorice 
Samoprocjenom poznavanja računovodstva je utvrđena srednja vrijednost od 3,18 (na skali od 1 do 5 pri čemu je 1- ,nedovoljno“, 2 - „,dovoljno“, 3 - „dobro“, 4 - „,vrlo dobro“ i 5 -,,izvrsno“) pri čemu samo 8\% ispitanika svoje znanje računovodstva smatra izvrsnim. Obzirom da ispitanici imaju različitu razinu obrazovanja iz različitih područja (utvrđena je široka lepeza zvanja od umjetničkih pa do tehničkih), ovakav nalaz ne predstavlja iznenađenje. Jonckheere-Terpstra testom je dana potvrda pretpostavci prema kojima poznavanje računovodstva pozitivno utječe na konzultiranje računovodstveno-financijske literature, korištenje savjetodavnih usluga na području računovodstva i redovito informiranje o računovodstvenim propisima. Dakle, oni predstavnici neprofitnih organizacija koji su uočili važnost poznavanja računovodstva i potrudili se naučiti temeljne računovodstvene pojmove, voljni su svoje spoznaje o računovodstvu produbiti proučavajući stručnu literaturu i legislativu te tražeći stručan savjet. Računovodstvo je ipak dinamično i kompleksno područje koje treba shvatiti ozbiljno jer je odraz odgovornosti neprofitne organizacije prema svim svojim dionicima. Upravo su odgovornost i transparentnost ključne u ostvarivanje povjerenja u neprofitne organizacije i jačanje njihovog kredibiliteta (Amagoh, 2015: 236).

Druga hipoteza je testirana (Tablica 4) ostvarivši statističku potporu. Utvrđen je pozitivan utjecaj razine poznavanja računovodstva na odlučivanje i planiranje $u$ neprofitnom sektoru.

Tablica 4: Rezultati Jonckheere-Terpstra testa za drugu hipotezu

\begin{tabular}{|c|c|c|c|c|}
\hline & Odlučivanje & $\begin{array}{c}\text { Smanjena } \\
\text { rizičnost }\end{array}$ & $\begin{array}{c}\text { Financijsko } \\
\text { planiranje }\end{array}$ & $\begin{array}{l}\text { Internalizacija } \\
\text { računovodstva }\end{array}$ \\
\hline $\begin{array}{l}\text { Broj razina u } \\
\text { Poznavanje } \\
\text { računovodstva }\end{array}$ & 5 & 5 & 5 & 5 \\
\hline $\mathrm{N}$ & 225 & 225 & 225 & 225 \\
\hline $\begin{array}{l}\text { Promatrana J-T } \\
\text { statistika }\end{array}$ & 11504,000 & 10382,500 & 11020,000 & 10627,500 \\
\hline Srednja J-T statistika & 9112,000 & 9112,000 & 9112,000 & 9112,000 \\
\hline $\begin{array}{l}\text { Std. devijacija oJ-T } \\
\text { statistike }\end{array}$ & 495,781 & 469,157 & 467,772 & 516,250 \\
\hline Std. J-T statistika & 4,825 & 2,708 & 4,079 & 2,936 \\
\hline $\begin{array}{l}\text { Signifikantnost } \\
\text { (dvostrana) }\end{array}$ &, 000 &, 007 &, 000 &, 003 \\
\hline
\end{tabular}

*Nezavisna varijabla: Poznavanje računovodstva

Izvor: Izrada autorice

Uvidom u rezultate (Tablica 4) dana je potpora hipotezi prema kojoj bolje poznavanje računovodstva pozitivno utječe na donošenje poslovnih odluka u neprofitnim organizacijama. Pretpostavka koja se odnosila na pozitivan utjecaj 
poznavanja računovodstva na financijsku pismenost koja umanjuje rizike kod donošenja poslovnih odluka te je Jonckheere-Terpstra testom i potvrđena. Pozitivan efekt poznavanja računovodstva na financijsko planiranje je također ostvario statističku potporu.

Obzirom da je prethodnim istraživanjima (Rogošić i Svirčić, 2015; Vašiček i sur., 2017) utvrđeno da većina neprofitnih organizacija ima eksternaliziranu funkciju računovodstva što znači da računovodstvene poslove prepušta stručnjacima izvan organizacije, zanimljivo je bilo utvrditi stav poznavatelja računovodstva među njima. Naime, rezultati ukazuju na to da oni koji bolje poznaju računovodstvo su mišljenja kako vođenje poslovnih knjiga unutar organizacije omogućuje prednosti. Najznačajnija prednost internalizacije računovodstva je u omogućavanju bržeg i detaljnijeg pristupa računovodstvenim informacijama potrebnih za upravljanje neprofitnom organizacijom.

Navedeni nalazi su u skladu s teorijskim pretpostavkama o sve većoj sličnosti korištenja računovodstvenih informacija u neprofitnom sektoru s načinima primijenjenim u poduzećima (Järvinen, 2016). Vjerojatan razlog tome počiva u činjenici da i neprofitne organizacije kao i poduzeća posluju u vrlo dinamičnom okruženju susrećući se sa snažnom konkurencijom u borbi za donacijama i drugim izvorima financiranja. Noviji koncepti menadžmenta neprofitnih organizacija (Aboramadan, 2018) daju dosta na važnosti računovodstvu kao osnovi za financijski menadžment i mjerenje performansi. Takav holistički pristup upravljanju neprofitnim organizacijama za cilj postavljaju dugoročnu održivost koja počiva na učinkovitosti i kredibilitetu (Amagoh, 2015). Poznavanje računovodstva koje za posljedicu ima bolje korištenje računovodstvenih informacija u upravljanju i odlučivanju u funkciji je postizanja bolje učinkovitosti i održivosti neprofitnih organizacija.

\section{ZAKLJUČNA RAZMATRANJA}

Neprofitne organizacije predstavljaju rastući sektor diljem svijeta sa snažnim utjecajem na kreiranje politika, a samim time i na društvo u cjelini. Obzirom da je uloga trećeg sektora sve značajnija, i važnost njegove održivosti se sve više ističe u literaturi. Jednu od ključnih uloga u ostvarivanju financijske stabilnosti i održivosti može imati mudro korištenje računovodstvenih informacija u planiranju i odlučivanju čemu prethodi poznavanje samog računovodstva.

Obzirom na mali broj istraživanja o ulozi računovodstva u upravljanju neprofitnim organizacijama diljem svijeta, doprinos ovog rada je upravo u rasvjetljavanju navedenog odnosa. Istraživanjem provedenim na neprofitnim organizacijama koje djeluju na teritoriju Republike Hrvatske je utvrđeno da se najviše prate 
računovodstveni propisi koji su u funkciji zadovoljavanja regulatornih računovodstvenih zahtjeva. Potvrđeno je da bolje poznavanje računovodstva (koje u prosjeku nije na visokoj razini) pozitivno utječe na donošenje odluka u trećem sektoru. Obzirom da u neprofitnim organizacijama među zakonskim zastupnicima, zaposlenicima i volonterima ekonomska struka nije zastupljena onoliko koliko u poduzećima, poznavanje računovodstva je ipak na nižim razinama. Unatoč tome, empirijski nalaz potvrđuje teorijske pretpostavke brojnih autora o sve većoj sličnosti upravljanja u profitnim i neprofitnim organizacijama. Obzirom da se $u$ suvremenom okruženju i neprofitne organizacije susreću s konkurencijom (posebice s aspekta izvora financiranja), a zahtjevi za njihovom efikasnošću su sve veći ovaj trend preuzimanja organizacijskih obrazaca karakterističnog za poduzeća ne iznenađuje. Stoga, i oslanjanje na računovodstvene informacije prilikom odlučivanja su logičan ishod navedenog trenda. Isto tako je utvrđeno da bolje poznavanje računovodstva pozitivno utječe na financijsku pismenost koja je $u$ funkciji smanjenja (operativnih, ali i drugih) rizika prilikom odlučivanja. Prema tome, računovodstvo i u neprofitnom sektoru preuzima ulogu relevantnog izvora informacija neophodnih za bolje upravljanje.

Posljednja izmjena računovodstvene regulative u Hrvatskoj (koja datira od 2015. godine) u funkciji je financijske održivosti, boljeg upravljanja i učinkovitosti neprofitnog sektora. Naime, Pravilnikom o sustavu financijskog upravljanja i kontrola te izradi i izvršavanju financijskih planova neprofitnih organizacija (Narodne novine, 119/2015) je propisana izrada financijskog plana za provedbu godišnjeg programa rada te je osim plana prihoda i rashoda, plana zaduživanja i otplata te obrazloženja financijskog plana pa je preporučeno budžetirati i novčani tijek radi bolje kontrole likvidnosti. Prema tome, poznavanje računovodstva posljedično rezultira boljim financijskim planiranjem.

Unatoč tome što većina neprofitnih organizacija ima eksternaliziranu funkciju računovodstva (odnosno vođenje poslovnih knjiga i sastavljanje financijskih izvještaja prepuštaju računovodstvenim stručnjacima van organizacije), postoji svjesnost o tome kako bi bolje bilo implementirati interni računovodstveni sustav posebice među boljim poznavateljima računovodstva kojima bi tako organizirano računovodstvo bilo dobar izvor relevantnih informacija. Takve informacije bi trebale biti u funkciji boljeg upravljanja performansama, ali i postizanju veće efikasnosti i odgovornosti prema zainteresiranim skupinama što vodi prema ostvarivanju većeg kredibiliteta $u$ javnosti. 


\section{LITERATURA}

1. Aboramadan, M. (2018). NGOs Management: A Roadmap to Effective Practices. Journal of Global Responsibility, 9(4), 372-387.

2. Amagoh, F. (2015). Improving the Credibility and Effectiveness of Non-governmental Organizations. Progress in Development Studies, 15(3), 221-239.

3. Eierle, B., Schultze, W. (2013). The Role of Management as a User of Accounting Information: Implications from Standard Setting. Accounting and Management Information Systems, 12(2), 155-189.

4. Goerke, J. (2003). Taking the quantum leap: Nonprofits are now in business - an Australian perspective. International Journal of Nonprofit and Voluntary Sector Marketing, 8(4), 317-327.

5. Gray, R., Bebbington, J., Collison, D. (2006). NGOs, Civil Society and Accountability: Making the People Accountable to Capital. Accounting, Auditing \& Accountability Journal, 19(3), 319-348.

6. Guay, T., Doh, J.P. and Sinclair, G. (2004). Non-governmental Organiziations Shareholder Activism and Socially Responsible Investments: Ethical, Strategic, and Governance Implications. Journal of Business Ethics, 52, 125-139.

7. Hall, M., Millo, Y. (2018). Choosing an Accounting Method to Explain Public Policy: Social Return on Investment and UK Non-profit Sector Policy. European Accounting Review, 27(2), 339-361.

8. Järvinen, J. T. (2016). Role of Management Accounting in Applying New Institutional Logics: A Comparative Case Study in the Non-profit Sector. Accounting, Auditing \& Accountability Journal, 29(5), 861-886.

9. Jegers M. (2008). Managerial Economics of Non-Profit Organizations, Routledge, London (UK)

10. Ježovita, A. (2015). Accounting Information in a Business Decision-Making Process - Evidence from Croatia. Zagreb International Review of Economics \& Business, 18(1), 61-79.

11. Kaplan, R.S. (2001). Strategic Performance Measurement and Management in Nonprofit Organizations, Nonprofit Management \& Leadership, 1(3), 353-369.

12. Maguire, K.A. (2012). Survey of Accounting, Auditing, and governance Practices of Non-Profit Organizations in South Carolina: A Research Service Learning Project. Business Management Dynamics, 2(2), 33-60.

13. Mamić Sačer, I., Dečman, N., Rep, A. (2018). Practical Problems in Understanding Accounting Terminology Used in the Preparation of General Purpose Financial Statements - Evidence from Croatia. Proceedings of the 7th 
International Scientific Symposium on Economy of Eastern Croatia - Vision and Growth, Location: Osijek, May 24-26, 2018, 1077-1085.

14. Mihanović, Z., Pavičić, J., Alfirević, N. (2014). Analysis of Organizational Performance of Non-profit Institutions: The Case of Lifelong Learning Institutions in Croatia. Economic Review - Journal of Economics and Business, 12(1), 3-13.

15. Nogueira, S.P.S., Jorge, S.M.F. (2017). The Perceived Usefulness of Financial Information for Decision Making in Portuguese Municipalities: The Importance of Internal Control. Journal of Applied Accounting Research, 18(1), 116-136.

16. Paiva, I., Carvalho, L. (2018). Accounting and Management Practices in the Third Sector in Angola. Economics \& Sociology, 11(3), 28-42.

17. Pravilnik o izvještavanju u neprofitnom računovodstvu i Registru neprofitnih organizacija, Narodne novine, br. 31/15

18. Pravilnik o neprofitnom računovodstvu i računskom planu, Narodne novine, br. $1 / 15$

19. Pravilnik o sustavu financijskog upravljanja i kontrola, izradi i izvršavanju financijskih planova neprofitnih organizacija, Narodne novine, br. 119/15

20. Prša Krunić, D., Dražić Lutilsky, I. (2012). Implementation of the Balanced Scorecard Model in a Non-profit Organization - A Virtual Secondary School Model. Sarajevo Business and Economics Review, 32, 33-52.

21. Reimann, K.D. (2006). A View from the Top: International Politics, Norms and the Worldwide Growth of NGOs. International Studies Quarterly, 50, 45-67.

22. Rogošić, A., Svirčić, M. (2016). Accounting Information for Planning and Control in Charitable Organizations, in: Rabar, D., Černe, K. i Zenzerović, R. (Eds.) EU Future Perspectives: Innovation, Entrepreneurship \& Economic Policy, Juraj Dobrila University of Pula, 1-11.

23. Royaee, R., Salehi, A., Aseman, H. S. (2012). Does Accounting Play a Significant Role in Managerial Decision-Making? Research Journal of Business Management and Accounting, 1(4), 57-63.

24. Socea, A. D. (2012). Managerial Decision-Making and Financial Accounting Information, Procedia - Social and Behavioral Sciences 58, 47-55.

25. Soobaroyen, T., Sannassee, R.V. (2007). An Exploratory Study of Financial Priorities, Financial Planning and Control Practices in Voluntary Organisations. Journal of accounting and Organizational Change, 3(3), 270-301.

26. Speckbacher, G. (2003). The Economics of Performance Management in Nonprofit Organizations. Nonprofit Management and Leadership, 13(3), 267-281. 
27. Tucker, B.P. and Parker, L.D. (2013). Managerial Control and Strategy in Nonprofit Organizations: Doing the Right Things for the Wrong Reasons? Nonprofit Management and Leadership, 24(1), 87-107.

28. Tunji, T. (2012). Accounting Information as an Aid to Management Decision Making. International Journal of Management and Social Sciences Research, 1(3), 29-34.

29. Unerman, J., O'Dwyer, B. (2006). On James Bond and the Importance of NGO Accountability. Accounting, Auditing \& Accountability Journal, 19(3), 305-318.

30. Vašiček, V., Dragija Kostić, M., Žmuk, B. (2017). User’s Satisfaction with the Accounting Information in Non-profit Organizations - Case of Croatia. Proceedings of the $26^{\text {th }}$ International Scientific Conference on Economic and Socual development - "Building Resilient Society", Location: Zagreb, 8-9 December 2017.

31. Werker, E. and Ahmed, F.Z. (2008). What Do Nongovernmental Organizations Do? Journal of Economic Perspectives, 22(2), 73-92.

32. Žager, K., Dečman, N. (2015). Računovodstvo malih i srednjih poduzeća. Hrvatska zahednica računovođa i financijskih djelatnika, Zagreb

33. Zakon o financijskom poslovanju i računovodstvu neprofitnih organizacija, Narodne novine, br. 121/14

34. Zakon o političkim strankama, Narodne novine, br. 76/93, 111/96, 164/98, 36/01, 28/06

35. Zakon o pravnom položaju vjerskih zajednica, Narodne novine, br. 83/02, $73 / 13$

36. Zakon o udrugama, Narodne novine, br. 74/14, 70/17

37. Zakon o ustanovama, Narodne novine, br. 76/93, 29/97, 47/99, 35/08

38. Zakon o zakladama i fundacijama, Narodne novine, br. 36/95, 64/01 


\title{
Andrijana Rogošić, PhD
}

University of Split, Faculty of Economics, Split, Croatia arogosic@efst.hr

\section{CONVERSANCE WITH ACCOUNTING IN NON-PROFIT ORGANISATIONS AND ITS IMPACT ON DECISION-MAKING AND FINANCIAL PLANNING}

Received: October 23, 2019

Accepted: December 6, 2019

https://doi.org/10.46458/27121097.2021.27.9

\section{Preliminary communication}

\begin{abstract}
Non-profit organisations (NPO) are focused on improving civil society and despite the fact that achieving profit does not represent their aim, non-profit organisations are becoming more like companies because they face strong competition in fundraising and the higher demands of their stakeholders for the increased effectiveness. New conceptual frameworks of NPO management emphasise performance management and financial management relying on accounting information. Therefore, understanding of accounting becomes crucial in achieving NPO success. However, as opposed to the companies that employ economists (who are familiar with accounting), NPOs usually lack in these experts and the questions regarding the understanding and the use of accounting information are being raised. Empirical research results indicate that conversance with accounting could be better in NPOs in Croatia. Hypotheses regarding the positive impact of conversance with accounting on decision-making and financial planning are supported.
\end{abstract}

Keywords: accounting, non-profit organisations, decision-making, financial planning

JEL: M41 